\title{
Twisted Blood Vessels: Symptoms, Etiology and Biomechanical Mechanisms
}

\author{
Hai-Chao Han \\ Department of Mechanical Engineering and Biomedical Engineering Program, University of Texas at San Antonio, \\ San Antonio, Tex., USA
}

\section{Key Words}

Vessel tortuosity · Artery tortuosity $\cdot$ Mechanical buckling $\cdot$

Wall remodeling $\cdot$ Mechanical instability

\begin{abstract}
Tortuous arteries and veins are commonly observed in humans and animals. While mild tortuosity is asymptomatic, severe tortuosity can lead to ischemic attack in distal organs. Clinical observations have linked tortuous arteries and veins with aging, atherosclerosis, hypertension, genetic defects and diabetes mellitus. However, the mechanisms of their formation and development are poorly understood. This review summarizes the current clinical and biomechanical studies on the initiation, development and treatment of tortuous blood vessels. We submit a new hypothesis that mechanical instability and remodeling could be mechanisms for the initiation and development of these tortuous vessels.
\end{abstract}

Copyright $\odot 2012$ S. Karger AG, Basel

\section{Introduction}

Tortuous or twisted arteries and veins are commonly seen in humans and animals [1-3]. While mild tortuosity is a common anomaly without clinical symptoms, severe tortuosity can lead to various serious symptoms. Clinical observations have linked tortuous arteries and veins to aging, atherosclerosis, hypertension, genetic defects and diabetes mellitus [4-8]. However, the mechanisms of tortuous vessel formation and development are poorly understood. Therefore, the mechanisms of vessel tortuosity need careful investigation.

The objectives of this paper are first to review the angiographic findings, clinical symptoms and treatment of tortuous blood vessels, and then to summarize the current clinical and biomechanical studies on their initiation and development.

\section{Symptoms}

\section{Clinical Phenotypes of Vessel Tortuosity}

Arteries are normally straight conduits that efficiently transport blood to distal organs. However, arteries may take a tortuous path due to abnormal development or vascular disease. Tortuous blood vessels have become a common angiographic finding in many studies and clinical screenings $[2,9,10]$. With the advance of imaging technology, more and more tortuous vessels are being detected $[2,11]$. Various forms have been reported in clinical investigations, most commonly curving/curling, angulation, twisting, looping and kinking vessels (fig. 1$)[1,6$, 12].

\section{KARGER}

Fax +4161306 1234

E-Mail karger@karger.ch

www.karger.com
(C) 2012 S. Karger AG, Basel

$1018-1172 / 12 / 0493-0185 \$ 38.00 / 0$

Accessible online at:

www.karger.com/jvr
Dr. Hai-Chao Han

Department of Mechanical Engineering

University of Texas at San Antonio

San Antonio, TX 78249 (USA)

Tel. +1 210458 4952, E-Mail hchan@utsa.edu 
Table 1. Tortuous vessel branches and associated diseases, with references

\begin{tabular}{|c|c|c|c|c|c|c|}
\hline Vessel branch & Aging & Atherosclerosis & Diabetes & Hypertension & Genetic & Other \\
\hline Aorta & {$[118,121][48,166]$} & {$[166,167]$} & & {$[67]$} & {$[7,94,97][67,101]$} & {$[166]$} \\
\hline Carotid & {$[4,58,59][64]$} & {$[4,13,57,58]$} & [113] & {$[1,4,6,12][63]$} & {$[60,95]$} & {$[73,98][122,168]$} \\
\hline $\begin{array}{l}\text { Vertebral, lingual, } \\
\text { or subclavian }\end{array}$ & {$[13,15]$} & {$[13]$} & {$[96]$} & {$[14,15]$} & {$[14,15][99,101]$} & {$[73][168]$} \\
\hline Iliac or femoral & {$[48]$} & {$[57,129,167]$} & & {$[16]$} & [16] & {$[2,10,62]$} \\
\hline Retinal & {$[22,81]$} & [88] & {$[8,22,82]$} & {$[20,78,79,91]$} & {$[79-81]$} & {$[18,88]$} \\
\hline Conjunctival & & & {$[8,83,84]$} & {$[8,83]$} & {$[8,83]$} & \\
\hline Capillary & {$[22]$} & {$[47]$} & {$[8,76]$} & {$[27,89,91]$} & & {$[25,26]$} \\
\hline Varicose vein & {$[106,107]$} & & {$[107]$} & {$[43,107]$} & & \\
\hline Collateral & {$[34]$} & {$[47]$} & & {$[3,44,46]$} & {$[3,44,46]$} & {$[33]$} \\
\hline
\end{tabular}

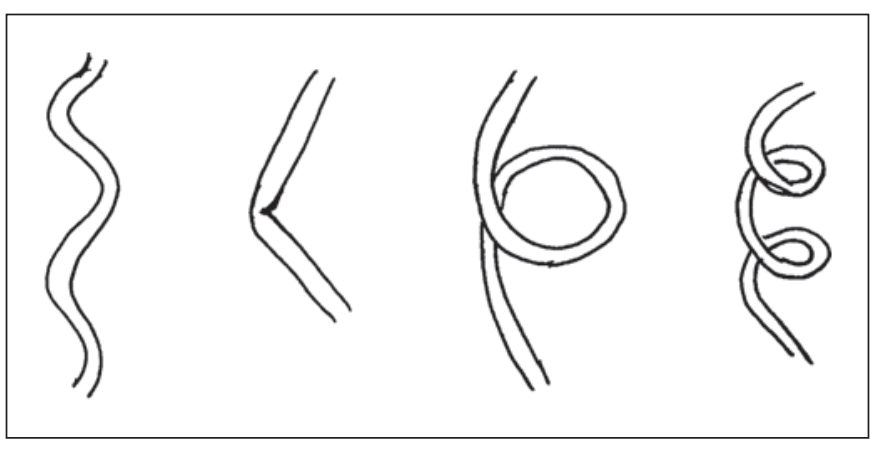

Fig. 1. Schematics of various phenotypes of tortuous vessels. Left to right: curving, angulation/kinking, looping and spiral twisting.

\section{Artery Tortuosity Is a Common Anomaly That}

Frequently Occurs in Many Vessels

Blood vessel tortuosity is a widely observed vascular anomaly affecting a range of vessels, from large arteries and veins to small arterioles and venules, in almost all locations in the body. Tortuosity has often been reported in the aorta and capillaries, as well as in the vertebral, iliac, femoral, coronary, cerebral and internal carotid arteries (see table 1).

Tortuosity and redundancy of the internal carotid artery is a common angiographic and MR angiographic finding $[1,2,9]$. In one of the largest angiographic studies conducted by Weibel and Fields [1], internal carotid artery tortuosity and angulation, respectively, were observed in 35 and $5 \%$ of 1,438 consecutive patients. Tortuous vertebral, subclavian and lingual arteries have also been reported [13-15]. Tortuous iliac and femoral arteries have been reported in some patients and cyclists $[2,16]$. Though rare, tortuosity has also been observed in other vascular branches in the arterial tree. These branches include, but are not limited to: the ulnar artery and radial and digital arteries [17-19]. It seems that tortuosity can affect almost all medial-sized arterial branches.

Tortuosity has also been frequently reported for small arteries and veins, most commonly in retinal and conjunctival vessels, due to their easy accessibility. Tortuous retinal arteries and veins have often been observed in patients with retinopathy and other diseases [20-22]. Tortuosity also happens in arterioles $[5,23,24]$ and capillaries $[22,25-28]$ in the skeletal muscle, myocardium and brain tissues, as well as in tumors [28, 29]. Tortuous coronary arteries have been observed in patients with hypertension and myocardial infarction [13, 30-33]. Tortuous cerebral arteries have been frequently reported, including the basilar, communicating, anterior and posterior cerebrals and the arterioles in white matter [5, 23, 24, 34-36].

In addition, tortuosity also occurs in veins and vascular grafts [37-39]. Arteries and veins may become tortuous after bypass grafting and reconstructive vascular surgery $[40,41]$. Twisting of vein grafts affects the patency of vein grafts [37-39]. Tortuous veins also occur in many patients with varicose veins due to vein valve disease $[42,43]$.

Furthermore, tortuosity often develops in collateral arteries after stenotic or occlusive disease in a major artery (fig. 2) [44-46]. The so-called 'corkscrew collaterals' are a widely observed phenomenon that hinders collateral development, a necessary component of arteriogenesis and tissue regeneration $[3,46,47]$. 


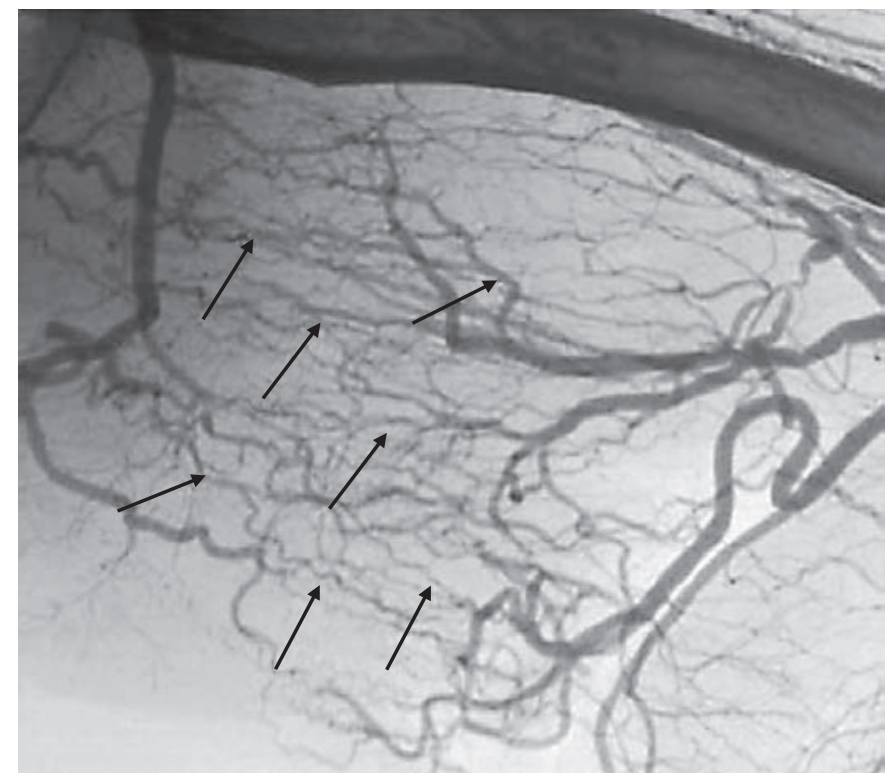

Fig. 2. Tortuous collaterals form after occlusion of a femoral artery (from [45]).

\section{Measurement of Vessel Tortuosity}

The level of vessel tortuosity is often described by the tortuosity indices. A commonly used tortuosity index is defined as the ratio of vessel curve length over the line distance between the two ends [32, 35, 48] (see fig. 3).

Alternatively, the tortuosity index can be defined as the total curvature or mean curvature, which calculates the cumulative sum of the angle between segment vectors normalized by vessel length [48-52]. A simplification of the index is the use of the ratio of deflection amplitude versus the wavelength $[53,54]$.

These indices can be determined from the images obtained from angiography and MR angiography and automatic approaches have been developed for the calculations $[49,52,55,56]$. In general, these indices depend on wavelength, wave number and wave amplitude. Vessel caliber may also play a role in evaluating the severity of vessel tortuosity [11].

\section{Etiology: Association with Vessel Diseases and Clinical Consequences}

With the advance of imaging technology and its wider application, many asymptomatic tortuous arteries are being diagnosed. While mild tortuosity in some patients is
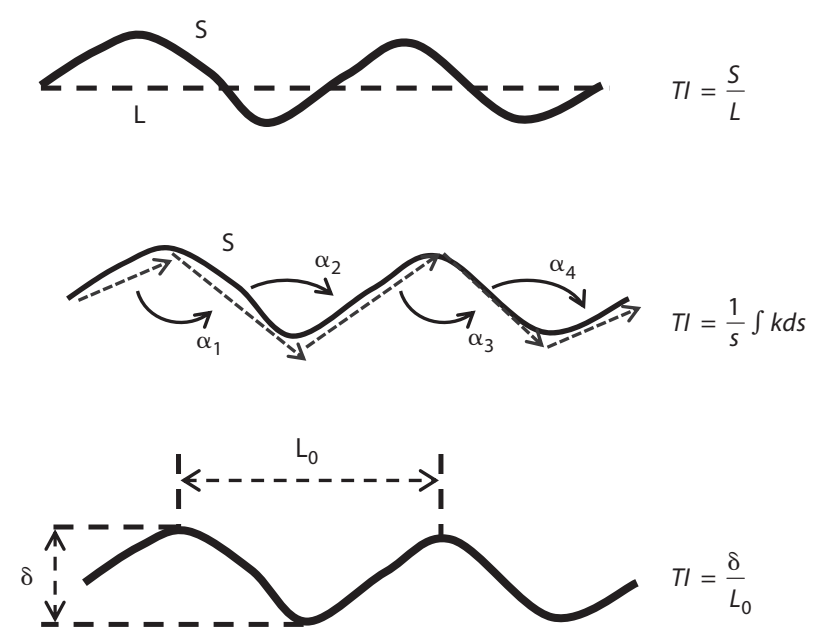

Fig. 3. Definitions of tortuosity indices. The integrated curvature of the middle panel is equal to the cumulative sum of angles $\alpha_{1}-$ $\alpha_{4}$.

asymptotic and often largely ignored, many others show symptoms linked to various vascular diseases (see table 1).

Extensive clinical studies have shown that artery tortuosity is associated with hypertension, aging, atherosclerosis and other pathological changes in the arteries $[4-8,13,24,33,57]$. It is often reported in elderly populations with severe tortuosity and angulation being associated with aging; it rarely occurs in children $[4,58$, 59]. The prevalence of artery kinking is tripled in the aged population and is quadrupled in the aged hypertensive population [6]. Severely tortuous arteries can hinder the blood flow and lead to a transit ischemic attack of distal organs [60]. Recent clinical studies have demonstrated that hypertensive pressure is a risk factor for artery tortuosity $[4-6,20]$. Below is a summary of some commonly seen vessel tortuosities and their associated diseases.

\section{Carotid Artery Tortuosity}

Clinical studies have shown that internal carotid artery tortuosity may lead to symptoms including dizziness, vertigo, syncopes, blackout or persistent tinnitus (ringing in the ears) [61]. Severe tortuosity may lead to arterial kinking (acute angulation) which causes artery occlusion and is associated with severe symptoms including transient ischemic attack, stroke [60], hemiplegia and 
other cerebrovascular deficiencies $[6,9,62]$. Tortuous carotid arteries are often reported in hypertensive patients $[4,6,63]$. They are often associated with atherosclerosis $[4,13,57]$ and there is speculation that they could be a factor leading to atherosclerosis [57]. Carotid artery tortuosity is often reported in elderly populations with severe tortuosity and angulation being associated with aging $[4,58,59,64]$. Reduced wall thickness or lumen diameter is associated with a higher prevalence of tortuosity, although there is discrepancy among the clinical reports on the correlation between atherosclerosis and artery tortuosity $[63,65]$. Arterial degenerative disease is often concomitant with internal carotid artery tortuosity, but is not always associated with it $[1,66-68]$.

\section{Cerebral Artery Tortuosity}

Tortuous cerebrals often occur in basilar, communicating, anterior and posterior cerebrals as well as in arterioles in the white matter $[5,23,24,34-36]$. Tortuosity of cerebral arteries has been reported for aged, hypertensive patients $[5,23,24,69]$ and in patients with 'Moyamoya' disease [70-72]. Cerebral arteries may also become tortuous due to malformation [73] or increased flow [34, 35] associated with elastin degradation. Tortuosity of cerebral arteries was found to be associated with the severity of hypertension [5].

\section{Coronary Artery Tortuosity}

Tortuosity of coronary arteries occurs in patients with hypertension and myocardial infarction [13, 30-33, 74]. Tortuosity is associated with increased acute occlusion of coronary arteries [75], diabetes [74-76] and coronary artery fistula [77]. Tortuous coronary arteries hamper ventricular function [31] and have been proposed as an indicator of ventricular dysfunction [30,31].

\section{Retinal Artery and Vein Tortuosity}

Tortuous retinal arteries and veins are associated with hypertension, diabetes and genetic disorders $[8,20,22$, $78-81]$. Tortuous conjunctival arteries and veins are also reported in patients with diabetic retinopathy $[8,82-84]$ and hypertension $[84,85]$. Tortuosity of retinal vessels has been suggested as an indicator of arterial hypertension, retinopathy, cerebral vessel disease, stroke and ischemic heart disease $[49,51,86-88]$.

\section{Tortuosity of Capillaries}

Tortuous capillaries have been observed in both skeletal muscles and in the myocardium [25-27, 76, 89] as well as in other organs $[8,22,90]$. Capillary tortuosity level increases and decreases with muscle contraction and relaxation allowing the vessel surface area and permeability to remain the same [26]; a higher level of tortuosity has been associated with hypertension and diabetes $[8,76,89,91]$.

\section{Artery Tortuosity Syndrome}

Artery tortuosity syndrome (ATS) is a rare condition caused by an autosomal recessive disorder (such as mutation of the SLC2A10 gene [7]) and characterized by tortuosity, elongation and aneurysm formation in major arteries due to the disruption of elastic fiber in the medial layer of the arterial wall. ATS is seen in members of the same family and affects all major arteries [7, 92, 93]. In addition, tortuous aortas have been observed in mice with an elastin gene knockout [79, 94-97].

\section{Loeys-Dietz Syndrome}

Artery tortuosity can also be associated with aneurysms $[48,98]$. Loeys-Dietz syndrome is a recently defined syndrome. Patients demonstrate tortuous aneurysmal vessels [99-101]. It is considered to be due to mutations in the TGFbeta receptor $[100,102]$. As aneurysmal arteries are prone to tortuosity, it is possible that tortuosity affects wall stress in aneurysms $[48,103]$, but the interaction needs further study.

\section{Varicose Veins}

Tortuous varicose veins cause morbidity and are a common manifestation of chronic venous disease [43]. Varicose veins are often associated with venous hypertension and valvular insufficiency $[42,43]$ and have a high prevalence in over one third of the population aged 50 years or older [104-107].

In addition to tortuous retinal veins, tortuous venules have been observed in cerebral, coronary, digital and other vascular beds $[24,33,108,109]$. Vein grafts may become tortuous under arterial pressure if not stretched sufficiently in the axial direction $[40,110]$. Venous tortuosity may affect blood flow and venous wall remodeling and therefore be associated with venous diseases; it has been reported that it leads to sluggish blood flow and thrombosis $[111,112]$.

While evidence strongly demonstrates the association of artery tortuosity and vein tortuositywith vascular diseases, the underlying mechanisms remain unclear and warrant further study to be understood. 


\section{Surgical Treatment of Tortuous Vessels}

While many mild tortuous arteries are left untreated, severely tortuous arteries with clinical symptoms can be treated with reconstructive surgery [61]. Severely tortuous or kinking carotid arteries have often been treated by surgical shortening reconstruction $[9,113,114]$. The surgical 'stripping' technique has been used [115]. The arteries are often treated while performing surgery for other vascular diseases such as stenosis, aneurysm or atherosclerosis $[9,116]$. Generally, surgical treatment achieves a better prognosis for symptomatic patients $[15,117]$.

\section{Mechanical Changes in Tortuous Arteries}

Clinical and experimental studies have demonstrated a strong association between vessel tortuosity and mechanical factors, such as blood pressure, blood flow, axial tension and wall structural changes.

First, artery tortuosity has been shown to be associated with hypertension $[4,5,33]$. Tortuosity of cerebral arteries was found to be associated with the severity of hypertension [5]. Vein pressure has also been associated with tortuosity in retinal veins $[87,91]$.

Second, artery tortuosity has been associated with reduced axial tension or elongation of the arteries. Normal arteries are subjected to a significant axial tension in vivo $[118,119]$. Certain levels of axial tension are essential in maintaining the stability of the arteries and preventing tortuosity. Axial tension may decrease with excessive growth of arteries and reduces with aging [118, 120, 121]; Jackson et al. [122] showed in a rabbit model that reduced axial tension by interpositional grafting in carotid arteries can lead to artery tortuosity.

Third, weakening of the arterial wall has been associated with tortuous vessels. Degradation of elastin, an important extracellular matrix component, weakens the arterial wall [123] and leads to tortuosity [98]. Elastin deficiency has been associated with tortuous arteries in patients with arterial tortuosity syndrome and LoeysDietz syndrome as well as in mice with an elastin gene knockout [79, 94-97, 124]. Increased blood flow also leads to tortuous cerebral arteries associated with elastin degradation $[34,35]$. The fragmentation of elastin has been reported in the artery wall of subjects with artery tortuosity and has been considered a cause of vessel lengthening $[66,68,121]$.

In addition, tortuous vessels occur when surrounding connective tissue degradation happens. It was reported that tortuous arterioles were associated with the development of small lacuna cavities (status lacunaris) in human basal ganglia [23]. In contrast, enhanced support of the surrounding tissue prevented vessel tortuosity $[40,125$, 126].

Combined, this evidence strongly suggests that hypertensive pressure, reduced axial tension and weakened wall stiffness may play an important role in the development of artery tortuosity.

On the other hand, tortuosity increases the resistance to blood flow and severe tortuosity can obstruct or even occlude blood flow $[33,62]$. Lumen shear stress and wall stress are also altered in tortuous arteries [127] (fig. 4). Computational simulations have confirmed this [128131]. Tortuous veins may also lead to thrombosis due to changes in the blood flow and shear stress [111, 132, 133].

While the clinical evidence strongly suggests that mechanical factors may play an important role in tortuous blood vessels, few studies have been conducted to determine the possible biomechanical mechanisms involved.

\section{Mechanical Stability of Blood Vessels}

Arteries are subjected to significant mechanical stresses generated by lumen blood flow, pressure and surrounding tissue tethering. These stresses are influenced by movement of the body, e.g. from walking, exercise and gravity. It has been well documented that mechanical stresses play important roles in regulating the function of vascular cells [134-137]. A high mechanical stress can lead to injury to the cells and damage to the vascular wall. It can also lead to mechanical instability and buckling of the blood vessels as tubular structures $[138,139]$. While the mechanical stress and strength of the arterial wall as a biological tissue have been extensively studied, there are few studies on the stability of arteries as a functional structure. The stability of blood vessels under lumen pressure is essential to maintain their physiological function. The complete understanding of arterial function and disease cannot be achieved without understanding the mechanical stability of arteries under pressure and flow.

It has been well documented that blood vessel lumen may collapse when internal pressure is too low or the external pressure exceeds the lumen pressure by a critical value [140]. Collapsible tube models have been developed to determine the critical pressures $[125,140-142]$. Re- 
Fig. 4. Comparison of stresses in normal and tortuous arteries. a Illustration of uniformly distributed lumen shear stress $(\tau)$ and tensile stresses in the axial, circumferential, axial and radial directions $\left(\sigma_{z}, \sigma_{\theta}\right.$ and $\sigma_{\mathrm{r}}$, respectively). b Velocity profile at 3 axial locations and wall shear stress variation along the bottom side in a sinusoidal vessel obtained from computational simulations. c Axial wall stress distribution along the circumference at 2 peak deflection locations.

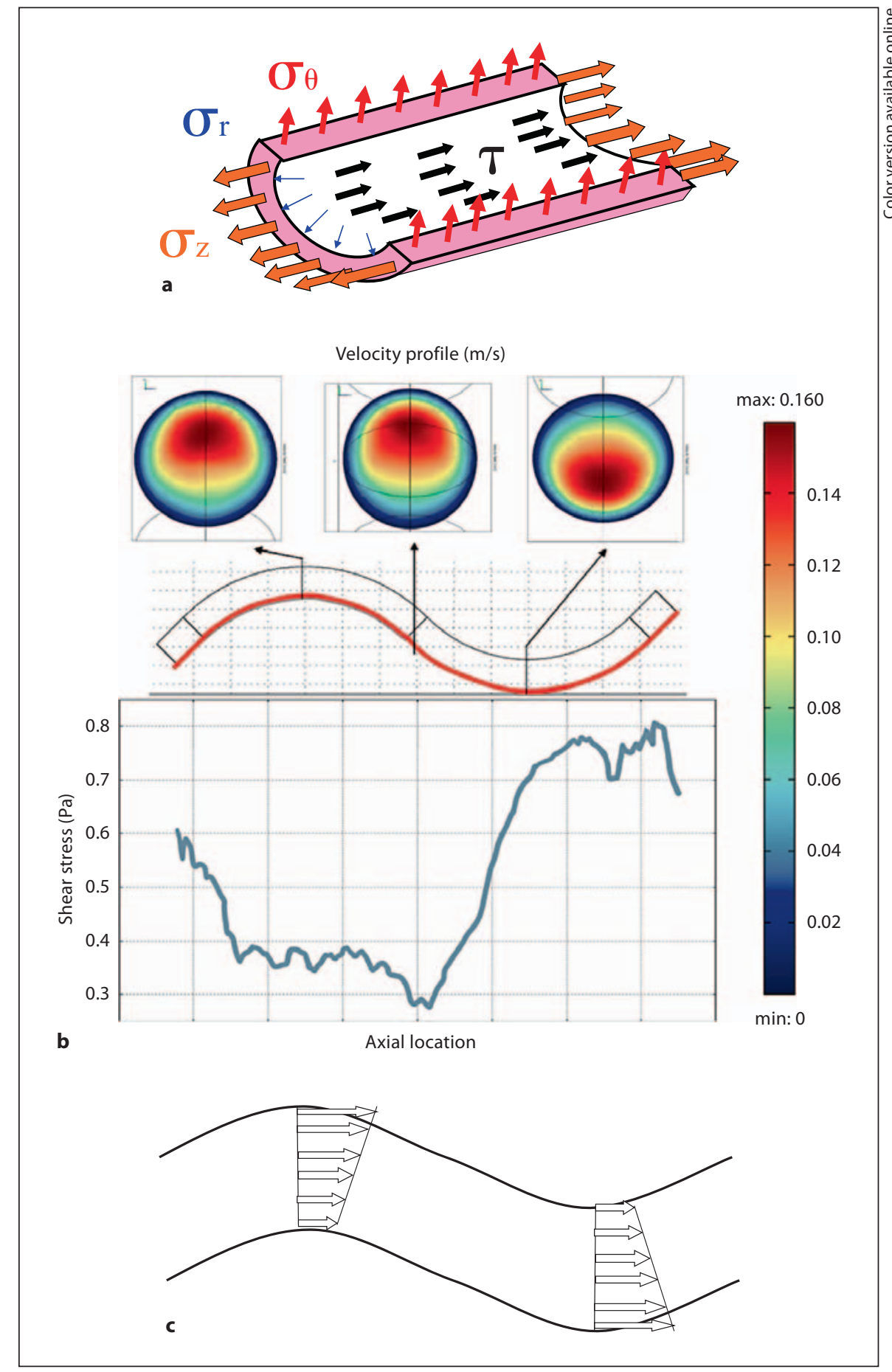

cently, Han $[138,139]$ demonstrated that long vessel segments under lumen pressure can become unstable when the lumen pressure exceeds a critical value. The phenomenon was termed 'vessel buckling' because it is similar to column-beam buckling. Buckling equations were estab- lished to estimate the critical pressure [138, 139, 143]. In fact, there were a few reports that modeled blood vessels as close-ended vessel segments under axial compression and used the linear elastic Euler buckling equation to estimate the critical pressure $[87,144,145]$. 
Artery Buckling under Lumen Pressure

Using both adjacent equilibrium and potential energy approaches, Han established an artery buckling model that predicted the critical load for bent buckling of long vessel segments [138, 139, 143]. The buckling equation is:

$$
p_{c r}=\frac{N}{\pi r_{i}^{2}}+\frac{E I}{\pi r_{i}^{2}}\left(\frac{n \pi}{l}\right)^{2}+\frac{k_{s}}{\pi r_{i}^{2}}\left(\frac{l}{n \pi}\right)^{2}
$$

where $k_{s}$ is the modulus of the surrounding matrix, $N$ is the axial force, $E I$ is the cross-sectional bending modulus, $l$ is the vessel length, $r_{i}$ is the lumen radius and $n$ is the wave number of the buckling mode shape $[138,139]$. Both $N$ and $E I$ are functions of the transmural pressure $p$ and the strains.

This model equation demonstrates that arteries buckle (and thus become tortuous) when lumen pressure exceeds a critical pressure at a given length. The critical pressures of blood vessels are determined by vessel dimensions, wall stiffness and axial tension $[53,146]$. The critical pressure decreases when there is a decrease in the axial stretch (tension), the mechanical stiffness of the arterial wall and/or the stiffness of the surrounding tissue. According to this equation, without surrounding matrix support $\left(k_{s}=0\right), p_{c r}$ is minimal at $n=1$ and with matrix support $\left(k_{s}>0\right)$; the 2 nd term in the equation increases with increasing wave number $n$ while the 3 rd term decreases. So a minimum buckling pressure is reached at a wave number $n>1$. Therefore, arteries buckle into multiple wave shapes within the surrounding tissue matrix at a higher critical pressure [138].

Experimental testing using porcine carotid arteries validated these model predictions. The critical pressures of porcine carotid arteries and veins decrease with reduced axial tension/stretch [53, 54, 127, 147, 148]. Although the classic linear elastic Euler column buckling model predicts a sudden, large, catastrophic increase of deflection with buckling, arteries do not show a sudden large deflection and catastrophic failure at buckling, but only a small deflection due to geometric nonlinearity $[139,149]$. The deflection of a buckled artery increases after buckling with increasing lumen pressure [148]. While arteries submerged in saline solution (without matrix support) buckle into single-wave shapes, arteries embedded in gelatin gel buckle into multi-wave shapes (fig. 5) [148]. It has also been observed that elastin degradation by elastase reduces the critical pressure of arteries associated with a reduced mechanical stiffness of the arterial wall [148].

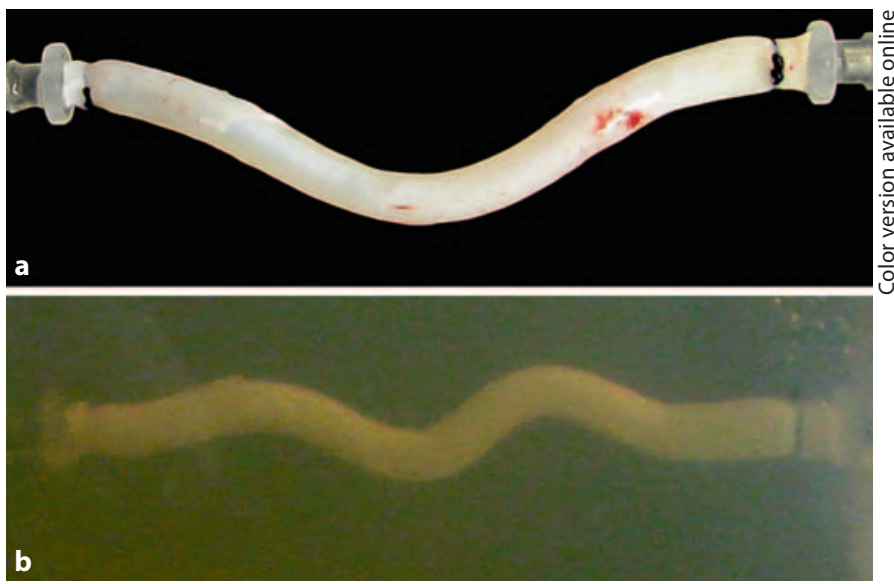

Fig. 5. Photographs of an artery within a supporting matrix under elevated internal pressure buckling into tortuous shapes. a Under an internal pressure $(140 \mathrm{~mm} \mathrm{Hg})$ beyond its critical pressure $(80$ $\mathrm{mm} \mathrm{Hg}$ ) in PBS solution. b Under an internal pressure $(230 \mathrm{~mm}$ $\mathrm{Hg}$ ) beyond its critical pressure $(150 \mathrm{~mm} \mathrm{Hg})$ in gelatin. (Photographed by Mr. Shawn Lamm in the author's laboratory).

Vessel buckling has been observed in vivo as well. Buckling of vein grafts under arterial pressure has been observed in vivo (e.g. [150]). It has been observed that canine vein grafts sometimes become tortuous immediately after being exposed to arterial pressure, and this buckling can be corrected by shortening the length of the graft (to increase the axial tension) $[40,126]$.

Further model analysis demonstrated that geometric variations such as initial curvature, tapering, eccentric or oval cross sections, stenosis and aneurysm often reduce the stability, as shown by the reduced critical pressures $[103,131,135,143,151]$.

\section{Comparison of Artery Buckling and Tortuosity}

Buckling is an instant deflection under internal pressure due to mechanical instability; arterial tortuosity is a chronic presentation as a result of arterial remodeling. Artery buckling initiates a small deflection that gradually increases if the pressure continues to increase [53, 148]. Tortuous vessels often demonstrate a finite amplitude of waviness.

While vessel buckling and vessel tortuosity are two different phenomena, buckled arteries and tortuous arteries demonstrate great similarities. First, their curved shapes look alike. Arteries surrounded by elastic matrix (gel) buckle into wavy shapes in vitro and tortuous arteries in vivo demonstrate waviness within the surrounding tissues. Second, the mechanical factors that cause buck- 
Fig. 6. A proposed new mechanism for the initiation and development of vessel tortuosity.

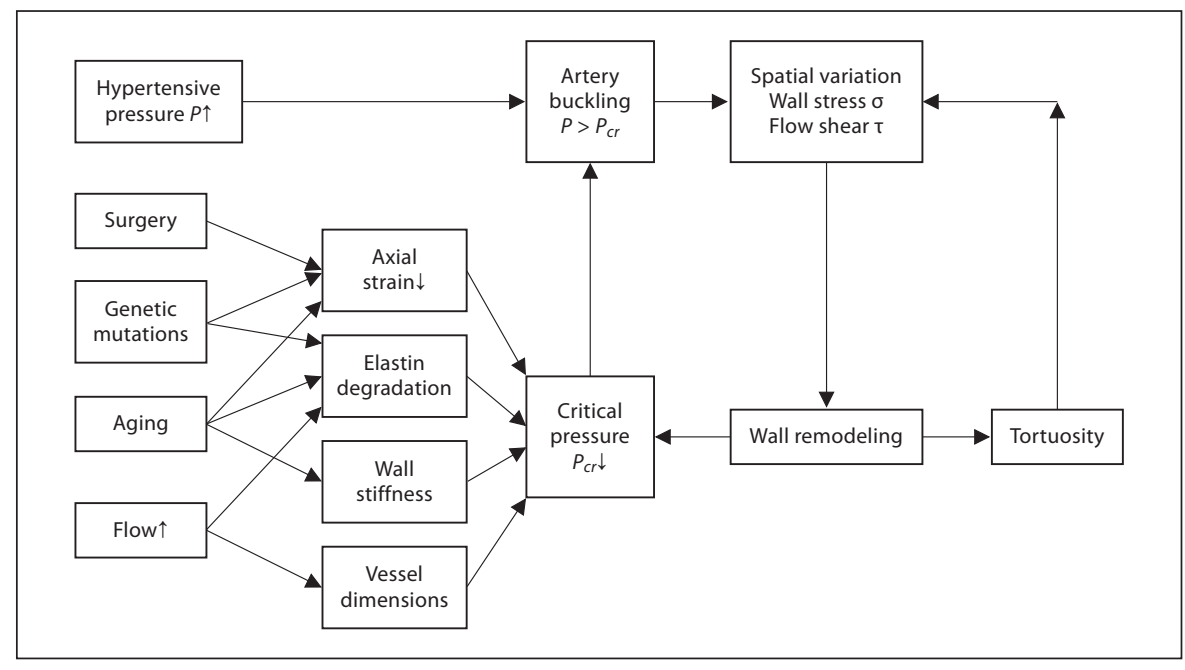

ling are a risk factor for patients. High blood pressure (hypertension), weakened wall due to internal elastic lamina/elastic fiber degradation and reduced axial stretch/tension not only lead to artery buckling in vitro and in vivo, but are also associated with a high prevalence of tortuosity in patients (as described in previous sections). A straight artery may develop into wavy tortuous shapes when the surrounding tissues are weakened by degenerative diseases. These similarities suggest a possible link between vessel buckling and vessel tortuosity. Furthermore, a recent in vivo experiment of rabbit carotid arteries and our ex vivo experimental evidence showed that axially offloaded arteries adapt over time and may become permanently tortuous in shape, suggesting that buckling may lead to tortuosity [122]. More research needs to be done to further elucidate the relationship between artery buckling and tortuosity.

\section{A New Hypothesis}

Based on the lines of evidence presented above, we submit a new hypothesis that mechanical instability and remodeling could be mechanisms for the initiation and development of tortuous blood vessels. We propose that mechanical buckling and the loss of mechanical stability could initiate the development of tortuous arteries. Buckling stimulates wall remodeling and the interaction between artery dynamics, buckling and wall remodeling leads to further development of vessel tortuosity.

Tortuosity may be caused by multiple factors: genetic factors, degenerative vascular diseases and an alteration in blood flow and pressure. Previous studies indicated that degenerative diseases, aging and genetic defects could also lead to artery buckling by altering wall properties and thus reducing the critical pressure (fig. 6). While buckling may not be the only possible mechanism of tortuosity, it seems to be a mechanism that links many of the factors that cause tortuosity.

\section{Future Challenges}

While we have gained some understanding of the development of tortuous vessels, there is a long way to go. There are many unanswered questions yet to be investigated.

\section{Buckling and Mechanical Stability under Pulsatile}

\section{Flow Need Investigation}

Arteries in vivo are under pulsatile pressure and flow. Artery buckling can lead to cyclic bending under pulsatile pressure. Dynamic analysis of artery stability demonstrated that arteries may become unstable under certain pulsatile pressures [152, 153]. Recent studies from the author's laboratory suggested that arteries under pulsatile pressure buckle when the peak pressure reaches the critical pressure as determined under static pressure [154]. However, further work needs to be done to better understand the artery buckling behavior under pulsatile pressure.

\section{The Effect of Bent Buckling on Blood Flow Needs Investigation}

Blood flow in the curved arteries, especially in the aorta, superior femoral arteries and coronary arteries, has 
been studied via experimental tests and numerical simulations $[129,155,156]$. Back et al. $[156,157]$ examined the flow in a human femoral artery model with reverse curvature and measured the flow in a sinusoidal coronary artery model. These and many other studies have shown that vessel curvature has significant effects on blood flow. Curvature increases pressure loss, flow resistance and secondary flow, as well as pressure and lumen shear stress on the outer curvature $[129,158]$. Results from computational fluid dynamics showed that the shear stress is approximately $60 \%$ higher on the outer wall than on the inner wall of a curved human right coronary artery [158]. However, buckled arteries and tortuous corkscrew collaterals are often severely tortuous. More studies are needed for severely and continuously tortuous arteries. It is unclear how the severity of arterial tortuosity is related to the level of flow alteration. However, artery buckling or tortuosity will lead to complex wall stress distributions in the arterial wall that vary circumferentially and longitudinally compared to the axisymmetric wall stress in straight cylindrical arteries [53, 151, 159]. A systemic study of the blood flow and wall stress analysis is needed to fully illustrate the stress alterations in the tortuous arteries due to the buckling effect.

It has been suggested that arterial tortuosity affects blood flow and may make the arteries prone to atherosclerosis $[4,57,129]$. By causing increased local stress concentrations, tortuosity may also render atherosclerotic plaques prone to rupture [160-162].

\section{Wall Remodeling in Buckled Arteries}

It is well known that both wall stress and shear stress influence vascular cell biology [134-137]. However, it is unclear how the tortuosity-induced flow and wall stress alterations affect the vascular cells and extracellular matrix and thus arterial wall remodeling. Previous studies have shown that the cyclic flexure of porcine femoral arteries affects extracellular matrix gene expression and cell proliferation $[163,164]$ and is related to atherosclerosis [159]. Similarly, our laboratory recently observed nonsymmetric cell proliferation in buckled arteries [165]. Further studies are needed to understand the long-term adaptation of the buckled artery.

Recent experimental evidence from animal models demonstrated that the development of tortuosity in cerebral arteries, secondary to flow increase, occurs as a gradual increase of the waviness that progresses over days and weeks $[34,35]$. The development of tortuosity of an artery is likely to stem from instability, i.e. the growth of small waviness. Such tortuosity development would have to in- volve interactions between arterial dynamics and active vascular remodeling. Mechanical buckling creates uneven mechanical stress on the inner and outer curve sides of the arterial wall and stimulates gradual, uneven wall remodeling [165] which creates an imperfection in the arterial wall and thus decreases the critical pressure for buckling. So the deflection will gradually magnify and buckling effects will be exacerbated under the same pressure. Future work is needed to investigate the development process of the buckling tortuosity.

\section{Conclusions}

Tortuosity is a common anomaly in arteries and veins associated with various vascular diseases and aging. The mechanisms underlying the initiation and development of tortuous arteries remain unclear. Fundamental understanding of the biomechanical mechanisms of artery tortuosity will have wide applications in vascular biology, physiology and pathology, as well as in vascular surgery. It will also be useful in understanding the 'corkscrew collateral' phenomenon in the development of collateral arteries, which is important in studying arteriogenesis and tissue regeneration.

Biomechanical studies of vessel buckling (mechanical instability) provide a promising new approach to elucidate the underlying mechanism of the initiation and development of vessel tortuosity. They also provide a basis for developing new techniques for the prevention and treatment of vessel tortuosity.

\section{Acknowledgments}

This work was supported by CAREER award No. 0644646 from the National Science Foundation and grant R01HL095852 from the National Institute of Health.

References
Weibel J, Fields WS: Tortuosity, coiling, and kinking of the internal carotid artery. I. Etiology and radiographic anatomy. Neurology 1965;15:7-18.

- 2 Schep G, Kaandorp DW, Bender $\mathrm{MH}$, Weerdenburg H, van Engeland S, Wijn PF: Magnetic resonance angiography used to detect kinking in the iliac arteries in endurance athletes with claudication. Physiol Meas 2001;22:475-487.

3 Helisch A, Schaper W: Arteriogenesis: the development and growth of collateral arteries. Microcirculation 2003;10:83-97. 
4 Del Corso L, Moruzzo D, Conte B, Agelli M, Romanelli AM, Pastine F, Protti M, Pentimone F, Baggiani G: Tortuosity, kinking, and coiling of the carotid artery: expression of atherosclerosis or aging? Angiology 1998; 49:361-371.

5 Hiroki M, Miyashita K, Oda M: Tortuosity of the white matter medullary arterioles is related to the severity of hypertension. Cerebrovasc Dis 2002;13:242-250.

6 Pancera P, Ribul M, Presciuttini B, Lechi A: Prevalence of carotid artery kinking in 590 consecutive subjects evaluated by echo-color Doppler. Is there a correlation with arterial hypertension? J Intern Med 2000;248:7-12.

$\checkmark 7$ Callewaert BL, Willaert A, KerstjensFrederikse WS, De Backer J, Devriendt K, Albrecht B, Ramos-Arroyo MA, Doco-Fenzy M, Hennekam RC, Pyeritz RE, Krogmann ON, Gillessen-Kaesbach G, Wakeling EL, Nik-Zainal S, Francannet C, Mauran P, Booth C, Barrow M, Dekens R, Loeys BL, Coucke PJ, De Paepe AM: Arterial tortuosity syndrome: clinical and molecular findings in 12 newly identified families. Hum Mutat 2008;29:150-158.

8 Owen CG, Newsom RS, Rudnicka AR, Barman SA, Woodward EG, Ellis TJ: Diabetes and the tortuosity of vessels of the bulbar conjunctiva. Ophthalmology 2008; 115 :e2732.

$\checkmark 9$ Grego F, Lepidi S, Cognolato D, Frigatti P, Morelli I, Deriu GP: Rationale of the surgical treatment of carotid kinking. J Cardiovasc Surg 2003;44:79-85.

10 Cheng CP, Wilson NM, Hallett RL, Herfkens RJ, Taylor CA: In vivo MR angiographic quantification of axial and twisting deformations of the superficial femoral artery resulting from maximum hip and knee flexion. J Vasc Interv Radiol 2006;17:979-987.

-11 Trucco E, Azegrouz H, Dhillon B: Modeling the tortuosity of retinal vessels: does caliber play a role? IEEE Trans Biomed Eng 2010;57: 2239-2247.

-12 Metz H, Murray-Leslie RM, Bannister RG, Bull JW, Marshall J: Kinking of the internal carotid artery. Lancet 1961;1:424-426.

13 Soikkonen K, Wolf J, Mattila K: Tortuosity of the lingual artery and coronary atherosclerosis. Br J Oral Maxillofac Surg 1995;33: 309-311.

14 Giuffre R, Sherkat S: The vertebral artery: developmental pathology. J Neurosurg Sci 1999;43:175-189.

$\checkmark 15$ Benes V, Netuka D: Surgical correction of symptomatic vertebral artery kinking. Br J Neurosurg 2003;17:174-178.

- 16 Dawson DL, Hellinger JC, Terramani TT, Najibi S, Martin LG, Lumsden AB: Iliac artery kinking with endovascular therapies: technical considerations. J Vasc Interv Radiol 2002;13:729-733.

17 Segal R, Machiraju U, Larkins M: Tortuous peripheral arteries: a cause of focal neuropathy. Case report. J Neurosurg 1992;76:701704 .
8 Jogiya A, Sandy C: Mild optic nerve hypoplasia with retinal venous tortuosity in Aarskog (facial-digital-genital) syndrome. Ophthalmic Genet 2005;26:139-141.

19 Ferris BL, Taylor LM Jr, Oyama K, McLafferty RB, Edwards JM, Moneta GL, Porter JM: Hypothenar hammer syndrome: proposed etiology. J Vasc Surg 2000;31:104-113.

20 Hayreh SS, Servais GE, Virdi PS: Retinal arteriolar changes in malignant arterial hypertension. Ophthalmologica 1989;198:178196.

21 Gekeler F, Shinoda K, Junger M, BartzSchmidt KU, Gelisken F: Familial retinal arterial tortuosity associated with tortuosity in nail bed capillaries. Arch Ophthalmol 2006; 124:1492-1494.

22 Amemiya T, Bhutto IA: Retinal vascular changes and systemic diseases: corrosion cast demonstration. Ital $\mathrm{J}$ Anat Embryol 2001;106:237-244.

23 Poni ES, Liwnicz BH, Ying-Ying Y, North M: Tortuosity of terminal arterioles in the basal ganglia is increased in status lacunaris. Invest Clin 2003;44:137-145.

24 Thore CR, Anstrom JA, Moody DM, Challa VR, Marion MC, Brown WR: Morphometric analysis of arteriolar tortuosity in human cerebral white matter of preterm, young, and aged subjects. J Neuropathol Exp Neurol 2007;66:337-345

25 Batra S, Rakusan K: Capillary length, tortuosity, and spacing in rat myocardium during cardiac cycle. Am J Physiol 1992;263:H13691376.

26 Mathieu-Costello O, Potter RF, Ellis CG, Groom AC: Capillary configuration and fiber shortening in muscles of the rat hindlimb: correlation between corrosion casts and stereological measurements. Microvasc Res 1988;36:40-55.

27 Pries AR, Secomb TW: Structural adaptation of microvascular networks and development of hypertension. Microcirculation 2002;9: 305-314.

28 Pries AR, Cornelissen AJ, Sloot AA, Hinkeldey M, Dreher MR, Hopfner M, Dewhirst MW, Secomb TW: Structural adaptation and heterogeneity of normal and tumor microvascular networks. PLoS Comput Biol 2009; 5:e1000394.

29 Vakoc BJ, Lanning RM, Tyrrell JA, Padera TP, Bartlett LA, Stylianopoulos T, Munn LL, Tearney GJ, Fukumura D, Jain RK, Bouma BE: Three-dimensional microscopy of the tumor microenvironment in vivo using optical frequency domain imaging. Nat Med 2009; 15:1219-1223.

30 Zegers ES, Meursing BT, Zegers EB, Oude Ophuis AJ: Coronary tortuosity: a long and winding road. Neth Heart J 2007; 15:191-195.

- 31 Turgut O, Yilmaz A, Yalta K, Yilmaz BM, Ozyol A, Kendirlioglu O, Karadas F, Tandogan I: Tortuosity of coronary arteries: an indicator for impaired left ventricular relaxation? Int J Cardiovasc Imaging 2007;23:671-677.
32 Jakob M, Spasojevic D, Krogmann ON, Wiher H, Hug R, Hess OM: Tortuosity of coronary arteries in chronic pressure and volume overload. Cathet Cardiovasc Diagn 1996;38: 25-31.

33 Hutchins GM, Miner MM, Bulkley BH: Tortuosity as an index of the age and diameter increase of coronary collateral vessels in patients after acute myocardial infarction. Am J Cardiol 1978;41:210-215.

34 Choy M, Ganesan V, Thomas DL, Thornton JS, Proctor E, King MD, van der Weerd L, Gadian DG, Lythgoe MF: The chronic vascular and haemodynamic response after permanent bilateral common carotid occlusion in newborn and adult rats. J Cereb Blood Flow Metab 2006;26:1066-1075.

- 35 Hoi Y, Gao L, Tremmel M, Paluch RA, Siddiqui $\mathrm{AH}$, Meng $\mathrm{H}$, Mocco J: In vivo assessment of rapid cerebrovascular morphological adaptation following acute blood flow increase. J Neurosurg 2008;109:1141-1147.

36 Sahni D, Jit I, Lal V: Variations and anomalies of the posterior communicating artery in Northwest Indian brains. Surg Neurol 2007; 68:449-453.

37 Boyle JR, Thompson MM, Clode-Baker EG, Green J, Bolia A, Fishwick G, Bell PR: Torsion and kinking of unsupported aortic endografts: treatment by endovascular intervention. J Endovasc Surg 1998;5:216-221.

38 Camiade C, Maher A, Ricco JB, Roumy J, Febrer G, Marchand C, Neau JP: Carotid bypass with polytetrafluoroethylene grafts: a study of 110 consecutive patients. J Vasc Surg 2003;38:1031-1037;(discussion)1038.

39 Dobrin PB, Hodgett D, Canfield T, Mrkvicka $\mathrm{R}$ : Mechanical determinants of graft kinking. Ann Vasc Surg 2001;15:343-349.

$\checkmark 40$ Han HC, Zhao L, Huang M, Hou LS, Huang YT, Kuang ZB: Postsurgical changes of the opening angle of canine autogenous vein graft. J Biomech Eng 1998;120:211-216.

-41 Canver CC: A draping technique for prevention of coronary bypass graft kinking and suture-line oozing. J Card Surg 1996;11:408410.

42 Pascarella L, Schmid Schonbein GW: Causes of telengiectasias, reticular veins, and varicose veins. Semin Vasc Surg 2005;18:2-4.

43 Bergan JJ, Pascarella L, Schmid-Schonbein GW: Pathogenesis of primary chronic venous disease: Insights from animal models of venous hypertension. J Vasc Surg 2008;47: 183-192.

44 Herzog S, Sager H, Khmelevski E, Deylig A, Ito $\mathrm{WD}$ : Collateral arteries grow from preexisting anastomoses in the rat hindlimb. Am J Physiol 2002;283:H2012-2020.

45 Schierling W, Troidl K, Troidl C, SchmitzRixen T, Schaper W, Eitenmuller IK: The role of angiogenic growth factors in arteriogenesis. J Vasc Res 2009;46:365-374.

46 Shireman PK, Quinones MP: Differential necrosis despite similar perfusion in mouse strains after ischemia. J Surg Res 2005;129: 242-250. 
47 Schaper W, Buschmann I: VEGF and therapeutic opportunities in cardiovascular diseases. Curr Opin Biotechnol 1999;10:541543.

-48 Wolf YG, Tillich M, Lee WA, Rubin GD, Fogarty TJ, Zarins CK: Impact of aortoiliac tortuosity on endovascular repair of abdominal aortic aneurysms: evaluation of 3D computer-based assessment. J Vasc Surg 2001;34:594-599.

49 Cheung CY, Zheng Y, Hsu W, Lee ML, Lau QP, Mitchell P, Wang JJ, Klein R, Wong TY: Retinal vascular tortuosity, blood pressure, and cardiovascular risk factors. Ophthalmology 2011;118:812-818.

-50 Hart WE, Goldbaum M, Cote B, Kube P, Nelson MR: Measurement and classification of retinal vascular tortuosity. Int J Med Inform 1999;53:239-252.

-51 Dougherty G, Johnson MJ, Wiers MD: Measurement of retinal vascular tortuosity and its application to retinal pathologies. Med Biol Eng Comput 2010;48:87-95.

-52 Koreen S, Gelman R, Martinez-Perez ME, Jiang L, Berrocal AM, Hess DJ, Flynn JT, Chiang MF: Evaluation of a computer-based system for plus disease diagnosis in retinopathy of prematurity. Ophthalmology 2007; 114:e59-e67.

53 Han HC: A biomechanical model of artery buckling. J Biomech 2007;40:3672-3678.

- 54 Martinez R, Fierro CA, Shireman PK, Han HC: Mechanical buckling of veins under internal pressure. Ann Biomed Eng 2010;38: 1345-1353.

55 Capowski JJ, Kylstra JA, Freedman SF: A numeric index based on spatial frequency for the tortuosity of retinal vessels and its application to plus disease in retinopathy of prematurity. Retina 1995;15:490-500.

-56 Grisan E, Foracchia M, Ruggeri A: A novel method for the automatic grading of retinal vessel tortuosity. IEEE Trans Med Imaging 2008;27:310-319.

57 Smedby O, Bergstrand L: Tortuosity and atherosclerosis in the femoral artery: what is cause and what is effect? Ann Biomed Eng 1996;24:474-480.

58 Thomas JB, Antiga L, Che SL, Milner JS, Steinman DA, Spence JD, Rutt BK: Variation in the carotid bifurcation geometry of young versus older adults: implications for geometric risk of atherosclerosis. Stroke 2005;36: 2450-2456.

-59 Lam RC, Lin SC, DeRubertis B, Hynecek R, Kent KC, Faries PL: The impact of increasing age on anatomic factors affecting carotid angioplasty and stenting. J Vasc Surg 2007;45: 875-880.

60 Cartwright MS, Hickling WH, Roach ES: Ischemic stroke in an adolescent with arterial tortuosity syndrome. Neurology 2006; 67:360-361.

61 Aleksic M, Schutz G, Gerth S, Mulch J: Surgical approach to kinking and coiling of the internal carotid artery. J Cardiovasc Surg 2004;45:43-48.
62 Schep G, Bender MH, van de Tempel G, Wijn PF, de Vries WR, Eikelboom BC: Detection and treatment of claudication due to functional iliac obstruction in top endurance athletes: a prospective study. Lancet 2002;359:466-473.

63 Oliviero U, Scherillo G, Casaburi C, Di Martino M, Di Gianni A, Serpico R, Fazio S, Sacca L: Prospective evaluation of hypertensive patients with carotid kinking and coiling: an ultrasonographic 7-year study. Angiology 2003;54:169-175.

64 Macchi C, Gulisano M, Giannelli F, Catini C, Pratesi C, Pacini P: Kinking of the human internal carotid artery: a statistical study in 100 healthy subjects by echocolor Doppler. J Cardiovasc Surg 1997;38:629-637.

65 Togay-Isikay C, Kim J, Betterman K, Andrews C, Meads D, Tesh P, Tegeler C, Oztuna D: Carotid artery tortuosity, kinking, coiling: stroke risk factor, marker, or curiosity? Acta Neurol Belg 2005;105:68-72.

66 Ochsner JL, Hughes JP, Leonard GL, Mills NL: Elastic tissue dysplasia of the internal carotid artery. Ann Surg 1977; 185:684-691.

67 Wagenseil JE, Nerurkar NL, Knutsen RH, Okamoto RJ, Li DY, Mecham RP: Effects of elastin haploinsufficiency on the mechanical behavior of mouse arteries. Am J Physiol 2005;289:H1209-H1217.

68 White JV, Haas K, Phillips S, Comerota AJ: Adventitial elastolysis is a primary event in aneurysm formation. J Vasc Surg 1993;17: 371-380;(discussion)380-371.

69 Spangler KM, Challa VR, Moody DM, Bell MA: Arteriolar tortuosity of the white matter in aging and hypertension. A microradiographic study. J Neuropathol Exp Neurol 1994;53:22-26.

-70 Burke GM, Burke AM, Sherma AK, Hurley MC, Batjer HH, Bendok BR: Moyamoya disease: a summary. Neurosurg Focus 2009; 26:E11.

71 Li H, Zhang ZS, Liu W, Yang WZ, Dong ZN, Ma MJ, Han C, Yang H, Cao WC, Duan L: Association of a functional polymorphism in the MMP-3 gene with Moyamoya disease in the Chinese Han population. Cerebrovasc Dis 2010;30:618-625.

72 Ruan LT, Duan YY, Cao TS, Zhuang L, Huang L: Color and power Doppler sonography of extracranial and intracranial arteries in Moyamoya disease. J Clin Ultrasound 2006;34:60-69.

-73 Hafeez F, Levine RL, Dulli DA: Pulsatile tinnitus in cerebrovascular arterial diseases. J Stroke Cerebrovasc Dis 1999;8:217-223.

74 Factor SM, Minase T, Cho S, Fein F, Capasso JM, Sonnenblick EH: Coronary microvascular abnormalities in the hypertensive-diabetic rat. A primary cause of cardiomyopathy? Am J Pathol 1984;116:9-20.

75 Ellis SG, Vandormael MG, Cowley MJ, DiSciascio G, Deligonul U, Topol EJ, Bulle TM: Coronary morphologic and clinical determinants of procedural outcome with angioplasty for multivessel coronary disease. Implications for patient selection. Multives- sel Angioplasty Prognosis study group. Circulation 1990;82:1193-1202.

76 Nemoto O, Kawaguchi M, Yaoita H, Miyake K, Maehara K, Maruyama Y: Left ventricular dysfunction and remodeling in streptozotocin-induced diabetic rats. Circ J 2006;70: 327-334.

-77 Said SA, Hofman MB, Beek AM, van der Werf T, van Rossum AC: Feasibility of cardiovascular magnetic resonance of angiographically diagnosed congenital solitary coronary artery fistulas in adults. J Cardiovasc Magn Reson 2007;9:575-583.

78 Hughes AD, Martinez-Perez E, Jabbar AS, Hassan A, Witt NW, Mistry PD, Chapman N, Stanton AV, Beevers G, Pedrinelli R, Parker KH, Thom SA: Quantification of topological changes in retinal vascular architecture in essential and malignant hypertension. J Hypertens 2006;24:889-894.

-79 Taarnhoj NC, Munch IC, Sander B, Kessel L, Hougaard JL, Kyvik K, Sorensen TI, Larsen M: Straight versus tortuous retinal arteries in relation to blood pressure and genetics. $\mathrm{Br}$ J Ophthalmol 2008;92:1055-1060.

80 Sutter FK, Helbig H: Familial retinal arteriolar tortuosity: a review. Surv Ophthalmol 2003;48:245-255.

-81 Vahedi K, Massin P, Guichard JP, Miocque S, Polivka M, Goutieres F, Dress D, Chapon F, Ruchoux MM, Riant F, Joutel A, Gaudric A, Bousser MG, Tournier-Lasserve E: Hereditary infantile hemiparesis, retinal arteriolar tortuosity, and leukoencephalopathy. Neurology 2003;60:57-63.

- 82 Cheng CH, Kikuchi T, Chen YH, Sabbagha NG, Lee YC, Pan HJ, Chang C, Chen YT: Mutations in the SLC2A10 gene cause arterial abnormalities in mice. Cardiovasc Res 2009; 81:381-388.

83 Cheung AT, Perez RV, Chen PC: Improvements in diabetic microangiopathy after successful simultaneous pancreas-kidney transplantation: a computer-assisted intravital microscopy study on the conjunctival microcirculation. Transplantation 1999;68: 927-932.

84 Cheung AT, Ramanujam S, Greer DA, Kumagai LF, Aoki TT: Microvascular abnormalities in the bulbar conjunctiva of patients with type 2 diabetes mellitus. Endocr Pract 2001;7:358-363.

-85 Eviatar A, Davis E: Systemic microcirculatory changes in otosclerotic patients (a biomicroscopic study). J Laryngol Otol 1968;82: 795-801.

86 Witt N, Wong TY, Hughes AD, Chaturvedi N, Klein BE, Evans R, McNamara M, Thom SA, Klein R: Abnormalities of retinal microvascular structure and risk of mortality from ischemic heart disease and stroke. Hypertension 2006;47:975-981.

-87 Kylstra JA, Wierzbicki T, Wolbarsht ML, Landers MB 3rd, Stefansson E: The relationship between retinal vessel tortuosity, diameter, and transmural pressure. Graefes Arch Clin Exp Ophthalmol 1986;224:477-480. 
88 Kwa VI, van der Sande JJ, Stam J, Tijmes N, Vrooland JL: Retinal arterial changes correlate with cerebral small-vessel disease. Neurology 2002;59:1536-1540.

-89 Hutchins PM, Marshburn TH, Maultsby SJ, Lynch CD, Smith TL, Dusseau JW: Longterm microvascular response to hydralazine in spontaneously hypertensive rats. Hypertension 1988;12:74-79.

90 Miodonski AJ, Litwin JA: Microvascular architecture of the human urinary bladder wall: a corrosion casting study. Anat Rec 1999;254:375-381.

-91 Bhutto IA, Amemiya T: Vascular changes in retinas of spontaneously hypertensive rats demonstrated by corrosion casts. Ophthalmic Res 1997;29:12-23.

92 Pletcher BA, Fox JE, Boxer RA, Singh S, Blumenthal D, Cohen T, Brunson S, Tafreshi P, Kahn E: Four sibs with arterial tortuosity: description and review of the literature. Am J Med Genet 1996;66:121-128.

$\$ 93$ Wessels MW, Catsman-Berrevoets CE, Mancini GM, Breuning MH, Hoogeboom JJ, Stroink H, Frohn-Mulder I, Coucke PJ, Paepe AD, Niermeijer MF, Willems PJ: Three new families with arterial tortuosity syndrome. Am J Med Genet A 2004;131: 134-143.

94 Nakamura T, Lozano PR, Ikeda Y, Iwanaga Y, Hinek A, Minamisawa S, Cheng CF, Kobuke K, Dalton N, Takada Y, Tashiro K, Ross J Jr, Honjo T, Chien KR: Fibulin-5/ DANCE is essential for elastogenesis in vivo. Nature 2002;415:171-175.

95 Wagenseil JE, Ciliberto CH, Knutsen RH, Levy MA, Kovacs A, Mecham RP: Reduced vessel elasticity alters cardiovascular structure and function in newborn mice. Circ Res 2009;104:1217-1224.

96 Coucke PJ, Willaert A, Wessels MW, Callewaert B, Zoppi N, De Backer J, Fox JE, Mancini GM, Kambouris M, Gardella R, Facchetti F, Willems PJ, Forsyth R, Dietz HC, Barlati S, Colombi M, Loeys B, De Paepe A: Mutations in the facilitative glucose transporter GLUT10 alter angiogenesis and cause arterial tortuosity syndrome. Nat Genet 2006;38:452-457.

-97 Yanagisawa H, Davis EC, Starcher BC, Ouchi T, Yanagisawa M, Richardson JA, Olson EN: Fibulin-5 is an elastin-binding protein essential for elastic fibre development in vivo. Nature 2002;415:168-171.

98 Dobrin PB, Schwarcz TH, Baker WH: Mechanisms of arterial and aneurysmal tortuosity. Surgery 1988;104:568-571.

-99 Kono AK, Higashi M, Morisaki H, Morisaki T, Tsutsumi Y, Akutsu K, Naito H, Sugimura K: High prevalence of vertebral artery tortuosity of Loeys-Dietz syndrome in comparison with Marfan syndrome. Jpn J Radiol 2010;28:273-277.

100 Loeys BL, Schwarze U, Holm T, Callewaert BL, Thomas GH, Pannu H, De Backer JF, Oswald GL, Symoens S, Manouvrier S, Roberts AE, Faravelli F, Greco MA, Pyeritz
RE, Milewicz DM, Coucke PJ, Cameron DE, Braverman AC, Byers PH, De Paepe AM, Dietz HC: Aneurysm syndromes caused by mutations in the TGF-beta receptor. N Engl J Med 2006;355:788-798.

- 101 Tran-Fadulu V, Pannu H, Kim DH, Vick GW 3rd, Lonsford CM, Lafont AL, Boccalandro C, Smart S, Peterson KL, Hain JZ, Willing MC, Coselli JS, LeMaire SA, Ahn C, Byers PH, Milewicz DM: Analysis of multigenerational families with thoracic aortic aneurysms and dissections due to TGFBR1 or TGFBR2 mutations. J Med Genet 2009;46:607-613.

102 Loeys B, De Paepe A: New insights in the pathogenesis of aortic aneurysms. Verh K Acad Geneeskd Belg 2008;70:69-84.

103 Northcutt A, Han HC: Finite element analysis of buckling of arteries with aneurysms. ASME Summer Bioengineering Conference, Lake Tahoe, 2009.

104 Campbell B: Varicose veins and their management. BMJ 2006;333:287-292.

105 Jones RH, Carek PJ: Management of varicose veins. Am Fam Physician 2008;78: 1289-1294.

106 Canonico S, Gallo C, Paolisso G, Pacifico F, Signoriello G, Sciaudone G, Ferrara N, Piegari V, Varricchio M, Rengo F: Prevalence of varicose veins in an Italian elderly population. Angiology 1998;49:129-135.

107 Komsuoglu B, Goldeli O, Kulan K, Cetinarslan B, Komsuoglu SS: Prevalence and risk factors of varicose veins in an elderly population. Gerontology 1994;40:25-31.

108 Meisel E, Pfeiffer D, Engelmann L, Tebbenjohanns J, Schubert B, Hahn S, Fleck E, Butter C: Investigation of coronary venous anatomy by retrograde venography in patients with malignant ventricular tachycardia. Circulation 2001;104:442-447.

109 Vattoth S, Purkayastha S, Jayadevan ER, Gupta AK: Bilateral cerebral venous angioma associated with varices: a case report and review of the literature. AJNR Am J Neuroradiol 2005;26:2320-2322.

110 Schneider PR, Pribaz J, Russell RC: Microvenous graft length determination for arterial repair. Ann Plast Surg 1986;17:292-298.

111 Liu Q, Mirc D, Fu BM: Mechanical mechanisms of thrombosis in intact bent microvessels of rat mesentery. J Biomech 2008; 41:2726-2734.

- 112 Dean LS, George CJ, Roubin GS, Kennard ED, Holmes DR Jr, King SB 3rd, Vlietstra RE, Moses JW, Kereiakes D, Carrozza JP Jr, Ellis SG, Margolis JR, Detre KM: Bailout and corrective use of gianturco-roubin flex stents after percutaneous transluminal coronary angioplasty: operator reports and angiographic core laboratory verification from the National Heart, Lung, and Blood Institute/New Approaches to Coronary Intervention Registry. J Am Coll Cardiol 1997;29:934-940.

113 Illuminati G, Calio FG, Papaspyropoulos V, Montesano G, D'Urso A: Revascularization of the internal carotid artery for isolated, stenotic, and symptomatic kinking. Arch Surg 2003;138:192-197.

114 Szekely G, Csecsei GI: Anteposition of the internal carotid artery for surgical treatment of kinking. Surg Neurol 2001;56:124126.

115 Bergan JJ, Kumins NH, Owens EL, Sparks SR: Surgical and endovascular treatment of lower extremity venous insufficiency. J Vasc Interv Radiol 2002;13:563-568.

116 Fearn SJ, McCollum CN: Shortening and reimplantation for tortuous internal carotid arteries. J Vasc Surg 1998;27:936-939.

117 Ballotta E, Thiene G, Baracchini C, Ermani M, Militello C, Da Giau G, Barbon B, Angelini A: Surgical versus medical treatment for isolated internal carotid artery elongation with coiling or kinking in symptomatic patients: a prospective randomized clinical study. J Vasc Surg 2005;42:838846; (discussion) 846 .

118 Nichols WW, O'Rourke MF: McDonald's Blood Flow in the Arteries. Theoretical, Experimental and Clinical Principles, ed 4. London, Arnold, 1998, chapt 16.

119 Han HC, Fung YC: Longitudinal strain of canine and porcine aortas. J Biomech 1995; 28:637-641.

120 Learoyd BM, Taylor MG: Alterations with age in the viscoelastic properties of human arterial walls. Circ Res 1966;18:278-292.

121 Sugawara J, Hayashi K, Yokoi T, Tanaka H: Age-associated elongation of the ascending aorta in adults. JACC Cardiovasc Imaging 2008;1:739-748.

122 Jackson ZS, Dajnowiec D, Gotlieb AI, Langille BL: Partial off-loading of longitudinal tension induces arterial tortuosity. Arterioscler Thromb Vasc Biol 2005;25:957-962.

123 Dobrin PB, Canfield TR: Elastase, collagenase, and the biaxial elastic properties of dog carotid artery. Am J Physiol 1984; 247:H124-131.

124 Carta L, Wagenseil JE, Knutsen RH, Mariko B, Faury G, Davis EC, Starcher B, Mecham RP, Ramirez F: Discrete contributions of elastic fiber components to arterial development and mechanical compliance. Arterioscler Thromb Vasc Biol 2009;29: 2083-2089.

125 Hamza LH, Dang Q, Lu X, Mian A, Molloi S, Kassab GS: Effect of passive myocardium on the compliance of porcine coronary arteries. Am J Physiol 2003;285:H653-660.

126 Yupu L, Yaotian H, Li Z, Rensheng L, Kaijun S, Ping M, Xiaochao C: Management of major arterial injuries of limbs: a study of 166 cases. Cardiovasc Surg 1993;1:486-488.

127 Lee AY: Determining the Critical Buckling of Blood Vessels through Modeling and in vitro Experiments; PhD, Biomedical Engineering San Antonio, University of Texas at San Antonio, 2011.

-128 Kaplan AD, Jaffa AJ, Timor IE, Elad D: Hemodynamic analysis of arterial blood flow in the coiled umbilical cord. Reprod Sci 2010;17:258-268. 
129 Wood NB, Zhao SZ, Zambanini A, Jackson M, Gedroyc W, Thom SA, Hughes AD, Xu $\mathrm{XY}$ : Curvature and tortuosity of the superficial femoral artery: a possible risk factor for peripheral arterial disease. J Appl Physiol 2006;101:1412-1418.

130 Qiao AK, Guo XL, Wu SG, Zeng YJ, Xu XH: Numerical study of nonlinear pulsatile flow in S-shaped curved arteries. Med Eng Phys 2004;26:545-552.

131 Datir P, Lee AY, Lamm SD, Han HC: Effects of geometric variations on the buckling of arteries. Int J Appl Mech 2011;3:385-406.

132 Klaritsch P, Haeusler M, Karpf E, Schlembach D, Lang U: Spontaneous intrauterine umbilical artery thrombosis leading to severe fetal growth restriction. Placenta 2008; 29:374-377.

133 Sato Y, Benirschke K: Umbilical arterial thrombosis with vascular wall necrosis: clinicopathologic findings of 11 cases. Placenta 2006;27:715-718.

134 Nerem RM: Role of mechanics in vascular tissue engineering. Biorheology 2003;40: 281-287.

135 Northcutt A, Datir P, Han HC: Computational simulations of buckling of oval and tapered arteries; in Chien S, SchmidSchönbein G, Tong P, Woo S (eds): Tributes to Yuan-Cheng Fung on His 90th Birthday. Hackensack, World Scientific, 2009.

136 Langille BL: Arterial remodeling: relation to hemodynamics. Can J Physiol Pharmacol 1996;74:834-841.

-137 Lehoux S, Tedgui A: Cellular mechanics and gene expression in blood vessels. J Biomech 2003;36:631-643.

138 Han HC: Blood vessel buckling within soft surrounding tissue generates tortuosity. J Biomech 2009;42:2797-2801.

139 Han HC: The theoretical foundation for artery buckling under internal pressure. J Biomech Eng 2009;131:124501.

140 Fung YC: Biomechanics: Circulation, ed 2. New York, Springer, 1997, chapter 4.

- 141 Drzewiecki G, Field S, Moubarak I, Li JK Vessel growth and collapsible pressure-area relationship. Am J Physiol 1997;273:H2030 H2043.

142 Downing JM, Ku DN: Effects of frictional losses and pulsatile flow on the collapse of stenotic arteries. J Biomech Eng 1997;119: 317-324.

143 Han HC: Determination of the critical buckling pressure of blood vessels using the energy approach. Ann Biomed Eng 2011;39: 1032-1040.

- 144 Brossollet LJ, Vito RP: An alternate formulation of blood vessel mechanics and the meaning of the in vivo property. J Biomech 1995;28:679-687.
145 Stelson KA, Blackshear PL Jr, Wirtschafter JD: On the tortuosity of the veins of the retina. Microvasc Res 1983;26:126-128.

146 Fierro CA, Johnson K, Han HC: The critical buckling pressure of arteries. ASME Summer Bioengineering Conference (SBC2007), Keystone, 2007.

147 Lee A, Han HC: A thin-walled nonlinear model for vein buckling. Cardiovasc Eng Tech 2010;1:282-289.

148 Lee AY, Han B, Lamm SD, Fierro CA, Han HC: Effects of elastin degradation and surrounding matrix support on artery stability. Am J Physiol Heart Circ Physiol 2012; 320:H873-H884.

149 Gere JM: Mechanics of Materials, ed 6. Belmont, Thomson, 2004.

150 Beris AE, Soucacos PN, Touliatos AS: Experimental evaluation of the length of microvenous grafts under normal tension. Microsurgery 1992;13:195-199.

151 Han HC: The mechanical buckling of curved arteries. Mol Cell Biomech 2009;6: 93-100.

152 Rachev A: A theoretical study of mechanical stability of arteries. J Biomech Eng 2009; 131:051006.

153 Rachev A, Gleason R: Dynamic instability of arteries. Effects of perivascular tissue. ASME Summer Bioengineering Conference, Lake Tahoe, 2009.

154 Liu Q, Han HC: Mechanical buckling of artery under pulsatile flow. ASME Summer Bioengineering Conference, Farmington, 2011.

$155 \mathrm{Ku}$ DN: Blood flow in arteries. Ann Rev Fluid Mech 1997;29:399-434.

156 Back LH, Back MR, Kwack EY, Crawford DW: Flow measurements in a human femoral artery model with reverse lumen curvature. J Biomech Eng 1988;110:300-309.

157 Back LH, Liem TK, Kwack EY, Crawford DW: Flow measurements in a highly curved atherosclerotic coronary artery cast of man. J Biomech Eng 1992;114:232-240.

58 Krams R, Wentzel JJ, Oomen JA, Vinke R, Schuurbiers JC, de Feyter PJ, Serruys PW, Slager CJ: Evaluation of endothelial shear stress and 3D geometry as factors determining the development of atherosclerosis and remodeling in human coronary arteries in vivo. Combining 3D reconstruction from angiography and IVUS (ANGUS) with computational fluid dynamics. Arterioscler Thromb Vasc Biol 1997;17:20612065.
59 Stein PD, Hamid MS, Shivkumar K, Davis TP, Khaja F, Henry JW: Effects of cyclic flexion of coronary arteries on progression of atherosclerosis. Am J Cardiol 1994;73: 431-437.

160 Li ZY, Howarth SP, Tang T, Graves MJ, J UK-I, Trivedi RA, Kirkpatrick PJ, Gillard $\mathrm{JH}$ : Structural analysis and magnetic resonance imaging predict plaque vulnerability: a study comparing symptomatic and asymptomatic individuals. J Vasc Surg 2007;45:768-775.

161 Huang H, Virmani R, Younis H, Burke AP, Kamm RD, Lee RT: The impact of calcification on the biomechanical stability of atherosclerotic plaques. Circulation 2001;103: 1051-1056.

162 Cheng GC, Loree HM, Kamm RD, Fishbein MC, Lee RT: Distribution of circumferential stress in ruptured and stable atherosclerotic lesions. A structural analysis with histopathological correlation. Circulation 1993;87:1179-1187.

163 Van Epps JS, Chew DW, Vorp DA: Effects of cyclic flexure on endothelial permeability and apoptosis in arterial segments perfused ex vivo. J Biomech Eng 2009;131: 101005.

164 Vorp DA, Peters DG, Webster MW: Gene expression is altered in perfused arterial segments exposed to cyclic flexure ex vivo. Ann Biomed Eng 1999;27:366-371.

165 Xiao Y, Zhao Y, Hayman D, Han HC: Arterial buckling promotes NF- $\kappa \mathrm{B}$ activation associated with cell proliferation in porcine carotid arteries perfused ex vivo. Biomedical Engineering Society Annual Conference, Hartford, Conn, 2011.

166 Avolio A, Jones D, Tafazzoli-Shadpour M: Quantification of alterations in structure and function of elastin in the arterial media. Hypertension 1998;32:170-175.

167 Choi G, Cheng CP, Wilson NM, Taylor CA Methods for quantifying three-dimensional deformation of arteries due to pulsatile and nonpulsatile forces: implications for the design of stents and stent grafts. Ann Biomed Eng 2009;37:14-33.

168 Okada Y, Shima T, Nishida M, Yamane K, Nakagawa I, Hori T: Intraoperative hemodynamic measurements of the vertebral artery and common carotid artery. Neurol Med Chir (Tokyo) 2004;44:509-515.

169 Ergul A, Elgebaly MM, Middlemore ML, Li W, Elewa H, Switzer JA, Hall C, Kozak A, Fagan SC: Increased hemorrhagic transformation and altered infarct size and localization after experimental stroke in a rat model type 2 diabetes. BMC Neurol 2007; $7: 33$ 